\title{
Penggunaan Tepung Keong Mas dan Suplementasi Probiotik dalam Ransum terhadap Performa Itik Peking
}

\section{(Use of Golden Snail Flour and Supplementation of Probiotics in Rations on the Performance of Pekin Duck)}

\author{
Daud M, Yaman MA, Latif H, Asril \\ Program Studi Peternakan, Fakultas Pertanian, Universitas Syiah Kuala \\ Kopelma Darussalam, Syiah Kuala, Kota Banda Aceh, Aceh 24411 \\ daewood_vt@yahoo.co.id
}

\begin{abstract}
The aim of the study is to evaluate golden snail flour (Pomacea canaliculata Lamarck) and supplementation of probiotics in rations on the performance of Pekin duck. The study used 100 DOD of Pekin duck. The study was designed into Completely Randomized Design consisting of 5 treatments and four replicates. Rations used during the first month was a commercial ration, and there after was ration as the treatments: $\mathrm{R} 1=$ Ration (control); $22=$ Ration containing of golden snail flour $4 \%$ and probiotic $0,5 \mathrm{ml}$; R3 = Ration containing of golden snail flour $6 \%$ and probiotic $0,5 \mathrm{ml} ; \mathrm{R} 4=$ Ration containing of golden snail flour $8 \%$ and probiotic $0,5 \mathrm{ml}$; and $\mathrm{R} 5=$ Ration containing of golden snail flour $10 \%$ and probiotic $0,5 \mathrm{ml}$. The observed variables feed consumption, body weight gain, final body weight, feed conversion, and mortality. Data was analiyzed by ANOVA and Duncan. The results showed that the golden snail flour and supplementation probiotics was significantly $(\mathrm{P}<0.05)$ influence on the performance of the Pekin duck. Effect of $8-10 \%$ golden snail flour and supplementation probiotics of ration significantly $(\mathrm{P}<0.05)$ on final body weight and feed conversion of Pekin duck. It is concluded that $8-10 \%$ golden snail flour and supplementation of $0.5 \mathrm{ml}$ probiotics in rations able to increase body weight gain and decrease mortality of Pekin duck.
\end{abstract}

Key Words: Ration, Golden Snail Flour, Probiotics, Performance, Pekin Duck

\begin{abstract}
ABSTRAK
Penelitian ini bertujuan untuk mengevaluasi performan itik Peking dengan penggunaan tepung keong mas (Pomacea canaliculata Lamarck) dan suplementasi probiotik dalam ransum. Materi penelitian 100 ekor DOD itik Peking ditempatkan dalam 5 perlakuan dan 4 ulangan. Ransum yang digunakan satu bulan pertama ransum komersial, dan satu bulan terakhir ransum perlakuan: R1 = Ransum (kontrol), $\mathrm{R} 2=$ Ransum mengandung $4 \%$ tepung keong mas dan 0,5 ml probiotik, R3 = Ransum mengandung $6 \%$ tepung keong mas dan $0,5 \mathrm{ml}$ probiotik, $\mathrm{R} 4=$ Ransum mengandung $8 \%$ tepung keong mas dan $0,5 \mathrm{ml}$ probiotik, dan $\mathrm{R} 5=$ Ransum mengandung $10 \%$ tepung keong mas dan $0,5 \mathrm{ml}$ probiotik. Variabel yang diamati: konsumsi ransum, pertambahan berat badan, berat badan akhir, konversi ransum dan mortalitas. Penelitian ini menggunakan Rancangan Acak Lengkap. Data dianalisis dengan ANOVA dilanjutkan uji Duncan. Hasil penelitian menunjukkan penggunaan tepung keong mas dan suplementasi probiotik $0,5 \mathrm{ml}$ dalam ransum berpengaruh nyata $(\mathrm{P}<0,05)$ terhadap performa itik Peking. Penggunaan tepung keong mas 8-10\% dan suplementasi probiotik $0,5 \mathrm{ml}$ dalam ransum secara signifikan $(\mathrm{P}<0.05)$ meningkatkan berat badan akhir dan konversi ransum. Disimpulkan bahwa penggunaan tepung keong mas $8-10 \%$ dan suplementasi probiotik $0,5 \mathrm{ml}$ dalam ransum mampu meningkatkan pertambahan bobot badan, dan menekan mortalitas itik Peking.
\end{abstract}

Kata Kunci: Ransum, Tepung Keong Mas, Probiotik, Performa, Itik Peking 


\section{PENDAHULUAN}

Ternak yang cukup potensial untuk menghasilkan daging dan cukup disenangi kehadirannya di tengah masyarakat adalah ternak unggas dan salah satunya yaitu ternak itik. Dari segi pemeliharaan, itik lebih sederhana sehingga masyarakat lebih mudah memeliharanya, lebih tahan terhadap penyakit dan pemberian pakannya lebih sederhana. Dalam usaha ternak itik yang dikelola secara intensif sekitar $60-70 \%$ biaya produksi adalah biaya pakan (Pramudyati 2002). Salah satu upaya menekan biaya produksi yaitu mengoptimalkan daya guna bahan pakan lokal yang terdapat di daerah tertentu, sehingga biaya pakan dapat ditekan tanpa harus mengganggu produktivitas ternak, salah satu contoh bahan pakan lokal yang dapat dijadikan sebagai sumber protein hewani sekaligus dapat menjadi sumber mineral yang dapat diformulasikan dalam ransum itik adalah tepung keong mas atau disebut siput murbai (Pomacea canaliculata Lamarck).

Kendala dalam memanfaatkan bahan pakan lokal antara lain tidak adanya jaminan keseragaman mutu dan kontinuitas produksi serta kandungan serat kasar yang tinggi sehingga sulit dicerna terutama ternak unggas. Purba \& Prasetyo (2014) menyatakan pemberian serat kasar tinggi 6-9\% masih dapat diterima terhadap respon pertumbuhan, produksi karkas dan mengurangi kandungan lemak abdominal pada itik pedaging EPMp hingga umur 12 minggu. Di samping itu, kemungkinan adanya faktor pembatas, misalnya zat racun atau anti nutrisi, dan keterbatasan kualitas karena kandungan protein, TDN, palatabilitas dan kecernaan yang rendah, sehingga memerlukan proses pengolahan terlebih dahulu sebelum digunakan sebagai pakan ternak (Mayulu et al. 2010). Untuk itu maka perlu dilakukan suatu strategi untuk memanfaatkan secara efektif dan efisien bahan-bahan pakan lokal sebagai bahan campuran dalam formulasi ternak itik sehingga populasi dan produksi ternak terus dapat dipacu (Daud et al. 2014). Ransum yang berbasis bahan pakan lokal diberikan oleh peternak biasanya dibuat berdasarkan usaha coba-coba sehingga kurang efisien karena ada kemungkinan kandungan nutriennya kurang mencukupi atau daya cerna terhadap ransum itu sendiri yang kurang sehingga nutrisi yang dapat diserap sangat sedikit.

Untuk mendapatkan hasil yang optimal maka perlu dilakukan penambahan probiotik dalam formulasi ransum itik. Penggunaan probiotik dalam ransum berguna sebagai mikroorganisme yang dapat membantu meningkatkan daya cerna pakan sehingga zat-zat nutrisi pada pakan dapat lebih banyak diserap oleh tubuh ternak untuk pertumbuhan maupun produksi. Penelitian ini bertujuan untuk mengevaluasi performa itik Peking dengan penggunaan tepung keong mas dan suplementasi probiotik dalam formulasi pakan lokal.

\section{MATERI DAN METODE}

\section{Materi penelitian}

Materi penelitian yang digunakan adalah tepung keong mas dan bahan pakan penyusun ransum lainnya (jagung, dedak halus, bungkil kelapa, sagu, tepung ikan, molases dan mineral mix serta probiotik) dan itik Peking sebanyak 100 ekor yang berumur 1 hari (DOD). Pemeliharaan itik Peking dilakukan selama 8 minggu yang ditempatkan dalam 5 perlakuan dan 4 ulangan.

\section{Ransum penelitian}

Ransum penelitian yang digunakan selama 1 bulan pertama adalah ransum komersial dan 1 bulan terakhir diberikan ransum perlakuan menggunakan tepung keong mas dengan 
jumlah yang berbeda disesuaikan dengan kebutuhan itik Peking umur 4-8 minggu yaitu kandungan protein 15-16\% dan energi metabolisme 2.900-3.000 kkal/kg (Tabel 1). Selama penelitian berlangsung ransum dan air minum diberikan secara ad libitum. Ransum perlakuan mulai diberikan pada itik Peking umur empat minggu.

Tabel 1. Susunan dan kandungan nutrisi ransum perlakuan

\begin{tabular}{lrrrrr}
\hline \multirow{2}{*}{ Bahan pakan } & \multicolumn{5}{c}{ Perlakuan ransum } \\
\cline { 2 - 6 } & $\mathrm{R}_{1}$ & $\mathrm{R}_{2}$ & $\mathrm{R}_{3}$ & $\mathrm{R}_{4}$ & $\mathrm{R}_{5}$ \\
\hline Tepung keong mas (\%) & 0,0 & 4,0 & 6,0 & 8,0 & 10,0 \\
Jagung (\%) & 30,0 & 35,0 & 35,0 & 35,0 & 40,0 \\
Dedak halus (\%) & 32,0 & 30,0 & 27,0 & 20,0 & 20,0 \\
Bungkil kelapa (\%) & 16,0 & 11,0 & 10,0 & 10,0 & 6,0 \\
Tepung ikan (\%) & 10,0 & 8,0 & 8,0 & 8,0 & 7,0 \\
Sagu (\%) & 10,0 & 10,0 & 12,0 & 17,0 & 15,0 \\
Molases (\%) & 1,0 & 1,0 & 1,0 & 1,0 & 1,0 \\
Mineral mix (\%) & 1,0 & 1,0 & 1,0 & 1,0 & 1,0 \\
\hline Total & 100,0 & 100,0 & 100,0 & 100 & 100 \\
\hline Probiotik (ml) & 0,0 & 0,5 & 0,5 & 0,5 & 0,5 \\
\hline Kandungan nutrisi & & & & & \\
\hline Protein (\%) & 16,0 & 16,1 & 16,6 & 16,8 & 16,8 \\
EM (kkal/kg) & 3014,8 & 3117,3 & 3114,7 & 3104 & 3018,2 \\
Lemak (\%) & 5,1 & 4,9 & 4,7 & 4,2 & 4,2 \\
SK (\%) & 6,2 & 5,5 & 5,6 & 4,7 & 4,2 \\
Methionine (\%) & 0,3 & 0,4 & 0,4 & 0,4 & 0,4 \\
Lysine (\%) & 0,7 & 0,8 & 0,8 & 0,8 & 0,8 \\
Ca (\%) & 0,7 & 0,6 & 0,6 & 0,6 & 0,6 \\
P (\%) & 0,9 & 0,8 & 0,6 & 0,6 & 0,6 \\
\hline & & & & &
\end{tabular}

\section{Proses pembuatan tepung keong mas}

Keong mas direndam dalam bak penampungan selama dua hari untuk mengurangi kotoran dan lendir yang dilanjutkan dengan pemberian garam dan diaduk selama 15 menit sampai lendir banyak keluar. Proses pemberian garam ini dapat dilakukan sebanyak dua kali, kemudian dicuci sampai bersih dari lendir. Selanjutnya keong direbus selama 20 menit dan ditiriskan, kemudian diangin-anginkan. Cangkang dipisahkan dari daging dengan alat pengungkit kemudian dicuci bersih. Daging keong mas dipotong tipis dan selanjutnya dikeringkan dengan sinar matahari sampai kering atau menggunakan oven dengan suhu dengan suhu $75-80^{\circ} \mathrm{C}$ selama 24 jam. Pengeringan dianggap selesai bila daging dapat dipatahkan dengan tangan. Proses selanjutnya daging keong digiling sampai halus hingga menjadi tepung keong mas.

\section{Variabel penelitian}

Variabel yang diamati meliputi: konsumsi ransum, pertambahan bobot badan, bobot badan akhir, konversi ransum, dan mortalitas. Konsumsi ransum diperoleh dari 
penimbangan jumlah ransum harian yang diberikan dikurangi dengan penimbangan sisa ransum harian. Pertambahan bobot badan diperoleh dari penimbangan berat badan akhir dikurangi dengan berat badan awal. Bobot badan akhir diperoleh dari bobot badan itik selama pemeliharaan tanpa dikurangi bobot badan awal, dan konversi ransum di peroleh dari perbandingan antara jumlah pakan yang dikonsumsi dengan pertambahan bobot badan yang dicapai.

\section{Rancangan penelitian dan analisis data}

Rancangan penelitian yang digunakan adalah rancangan acak lengkap (RAL) yang terdiri atas 5 perlakuan dan 4 ulangan dan setiap ulangan terdiri 5 ekor itik Peking. Data yang diperoleh dianalisis dengan sidik ragam atau Analysis of Variance (ANOVA) menggunakan General Linear Model Procedure (SPSS Version 13.0 for Windows) dan jika memberikan hasil yang berbeda nyata dilanjutkan dengan Uji Duncan (Steel \& Torrie 1995).

\section{HASIL DAN PEMBAHASAN}

\section{Konsumsi ransum}

Konsumsi ransum merupakan aspek terpenting dalam melakukan evaluasi terhadap nutrisi pakan. Pemberian ransum dengan formulasi tepung keong mas dan suplementasi probiotik pada itik Peking diperoleh variasi nilai konsumsi ransum. Rerata konsumsi ransum masing-masing perlakuan secara akumulatif umur 5-8 minggu ditampilkan pada Tabel 2.

Tabel 2. Rerata konsumsi ransum, bobot badan akhir, konversi ransum dan mortalitas itik Peking umur 8 minggu

\begin{tabular}{lccccc}
\hline \hline \multirow{2}{*}{ Variabel } & \multicolumn{5}{c}{ Perlakuan ransum } \\
\cline { 2 - 6 } & $\mathrm{R} 1$ & $\mathrm{R} 2$ & $\mathrm{R} 3$ & $\mathrm{R} 4$ & $\mathrm{R} 5$ \\
\hline $\begin{array}{l}\text { Konsumsi } \\
\text { ransum (g/ekor) }\end{array}$ & $6334,5 \pm 61,6$ & $6343,0 \pm 93,8$ & $6428,8 \pm 189$ & $6567,7 \pm 95,7$ & $6657,7 \pm 29,9$ \\
$\begin{array}{l}\text { Bobot badan } \\
\text { akhir (g/ekor) }\end{array}$ & $1530,5 \pm 40,7^{\mathrm{a}}$ & $1665,7 \pm 12,3^{\mathrm{a}}$ & $1690,5 \pm 47,3^{\mathrm{a}}$ & $1802,0 \pm 69,7^{\mathrm{b}}$ & $1886,5 \pm 64,0^{\mathrm{b}}$ \\
$\begin{array}{l}\text { Konversi ransum } \\
\text { Mortalitas (\%) }\end{array}$ & $5,14 \pm 0,20^{\mathrm{b}}$ & $5,01 \pm 0,52^{\mathrm{b}}$ & $4,98 \pm 0,28^{\mathrm{b}}$ & $4,37 \pm 0,15^{\mathrm{a}}$ & $4,19 \pm 0,16^{\mathrm{a}}$ \\
\hline
\end{tabular}

Nilai rata-rata dengan superskrip yang berbeda pada baris yang sama menunjukkan pengaruh yang berbeda nyata $(\mathrm{P}<0,05)$

Hasil analisis menunjukkan bahwa tidak ada peningkatan jumlah penggunaan level tepung keong mas dalam formulasi ransum (8-10\%). Hal ini diduga karena dosis penggunaan tepung keong mas dalam formulasi ransum dan penambahan probiotik belum dapat meningkatkan palatabilitas ransum. Hasil penelitian ini berbeda seperti yang dilaporkan oleh Amarullah (2010), bahwa pemberian level tepung keong mas pada taraf 15\% dalam ransum itik Tegal cenderung menurunkan jumlah konsumsi, sementara pada itik Bali peningkatan level keong mas dalam ransum diikuti dengan meningkatnya konsumsi ransum, namun berdasarkan hasil penelitiannya penggunaan tepung keong mas dalam ransum pada level 5-10\% pada kedua varietas itik (Tegal dan Bali) tidak 
mempengaruhi turunnya angka konsumsi ransum. Hasil penelitian Daud et al. (2015), konsumsi ransum itik Peking dengan penggunaan hijauan kangkung fermentasi dalam ransum berkisar antara 6.476,7-6.705,3 g/ekor selama empat minggu pemberian.

Menurut Wahyu (2004), konsumsi ransum dapat dipengaruhi oleh besar dan berat badan ternak, kondisi fisiologis ternak serta laju makanan dalam pencernaan ternak. Laju makanan dalam pencernaan mempengaruhi jumlah makanan yang dikonsumsi, yakni semakin cepat aliran makanan dalam alat pencernaan semakin banyak pula jumlah makanan yang dikonsumsi. Konsumsi ransum pada ternak dapat dipengaruhi oleh berbagai faktor, salah satu faktor utama menurut Hernandez et al. (2004) adalah kualitas pakan termasuk kandungan gizi yang terdapat di dalam pakan tersebut. Konsumsi ransum juga sangat dipengaruhi oleh palatabilitas ransum, jenis, dan komposisi penggunaan bahan pakan dalam formulasi ransum itik Peking (Daud et al. 2013).

\section{Pertambahan bobot badan dan bobot badan akhir}

Pertambahan bobot badan merupakan salah satu variabel yang dapat digunakan sebagai standar performa itik Peking. Rerata pertambahan bobot badan itik Peking per minggu selama penelitian ditampilkan pada Gambar 1.

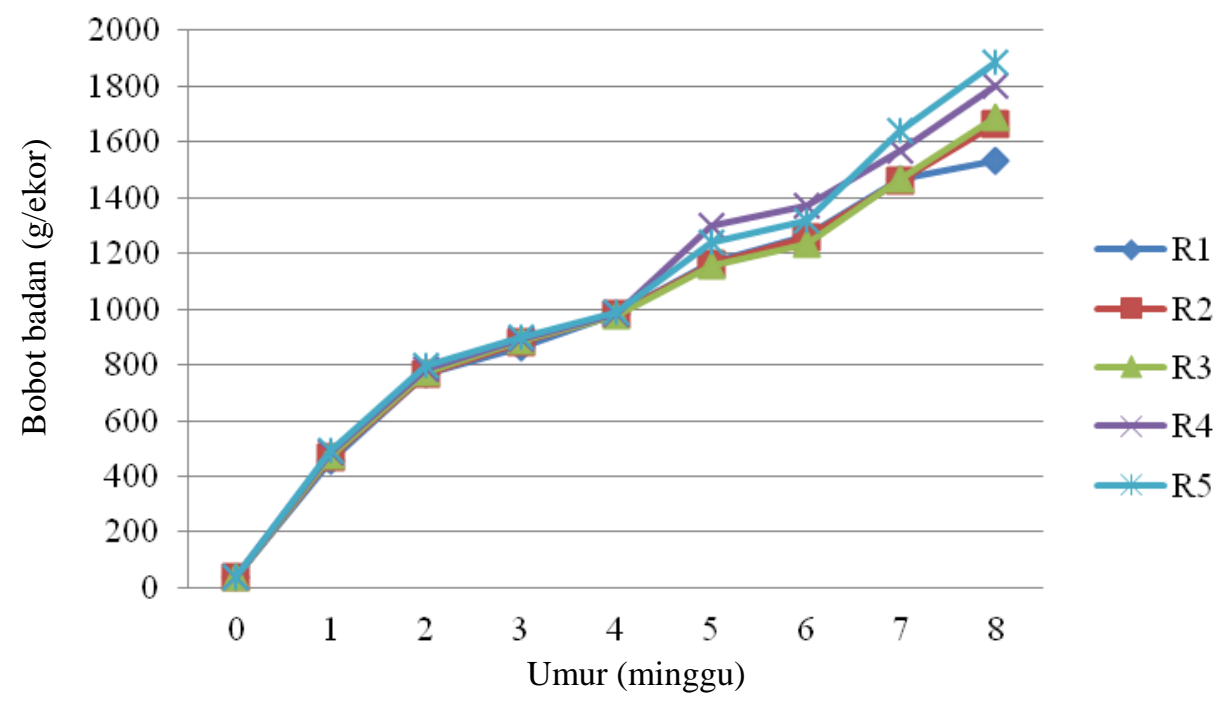

Gambar 1. Laju pertumbuhan itik Peking selama delapan minggu

Hasil penelitian menunjukkan bahwa pertambahan bobot badan itik Peking dengan penggunaan $8-10 \%$ tepung keong mas dan suplementasi $0,5 \mathrm{ml}$ probiotik dalam ransum lebih tinggi $(\mathrm{P}<0,05)$ dibandingkan dengan perlakuan lainnya dan perlakuan kontrol. Hasil penelitian ini menunjukkan bahwa ransum yang mengandung tepung keong mas pada taraf 8-10\% dan disuplementasi dengan probiotik dapat memberikan keseimbangan serta kualitas yang baik terhadap kadar nutrisi dalam ransum sehingga meningkatkan pertambahan bobot badan. Hal ini sesuai dengan pendapat Fuller (1997), bahwa untuk mencapai tingkat pertumbuhan optimal sesuai dengan potensi genetik, diperlukan makanan yang mengandung unsur gizi secara kualitatif dan kuantitatif. Tingginya pertambahan bobot badan juga disebabkan oleh tingkat konsumsi ransum. Hal tersebut sesuai dengan pernyataan Kartadisasra (1997), bahwa pertambahan bobot badan ternak senantiasa berbanding lurus dengan konsumsi ransum, semakin besar bobot badan semakin banyak jumlah konsumsi ransumnya. Pengaruh lain terhadap tingginya pertambahan bobot badan itik Peking yang diberikan ransum mengandung tepung keong mas dan suplementasi 
probiotik, dengan ransum tanpa tepung keong mas dan suplementasi probiotik disebabkan efek penggunaan probiotik dalam ransum yang dapat meningkatkan daya cerna, dan akhirnya dapat meningkatkan pertambahan berat badan itik Peking. Fuller (1997) melaporkan bahwa pemberian probiotik dapat meningkatkan pertumbuhan ternak, meningkatkan kecernaan bahan pakan, meningkatkan daya tahan tubuh, meningkatkan pertumbuhan mikroba yang menguntungkan, dan probiotik bekerja dalam meningkatkan pertambahan bobot badan itik Peking. Jin et al. (2000) menyatakan bahwa suplementasi probiotik Lactobacillus sp. mampu meningkatkan aktivitas enzim lipolitik, proteolitik, dan amilolitik pada usus halus. Peningkatan aktivitas enzim pencernaan kemungkinan juga disebabkan oleh probiotik dalam memperbaiki pertumbuhan sel epitel usus dimana pada bagian tersebut mensekresikan enzim-enzim pencernaan (Hidayat et al. 2016). Oleh sebab itu pakan yang dikonsumsi dapat dicerna dan diabsorbsi secara optimal sehingga kebutuhan nutrien akan terpenuhi secara baik.

Bobot badan akhir itik Peking yang diperoleh pada hasil penelitian ini berkisar antara 1530,5-1886,5 g/ekor (Tabel 2). Hasil penelitian ini menunjukkan bahwa penggunaan tepung keong mas sebanyak $8-10 \%$ dan suplementasi $0,5 \mathrm{ml}$ probiotik dalam formulasi ransum itik Peking secara nyata $(\mathrm{P}<0,05)$ meningkatkan berat badan akhir dibandingkan dengan tanpa penggunaan tepung keong mas dan suplementasi probiotik dalam formulasi ransum. Sedangkan penggunaan tepung keong mas 4-6\% dan suplementasi $0,5 \mathrm{ml}$ probiotik dalam ransum tidak menunjukkan perbedaan yang signifikan. Tingginya bobot badan akhir itik Peking dengan penggunaan tepung keong mas 8-10\% dan suplementasi probiotik disebabkan oleh kualitas ransum yang baik dan seimbang kandungan nutrisinya, sehingga berat badan akhir lebih tinggi. Sesuai dengan pernyataan Parakkasi (1985) bahwa pertambahan bobot badan sangat dipengaruhi oleh kualitas ransum. Penggunaan tepung keong mas pada level 8-10\% menyebabkan peningkatan kualitas ransum karena tepung keong mas tinggi kandungan protein dan kalsium sekaligus dapat menggantikan tepung ikan dalam ransum itik. Rerata bobot badan akhir itik Peking yang diperoleh pada penelitian ini tidak berbeda jauh dengan hasil penelitian Daud et al. (2016) yaitu berkisar antara 1533,3-1866,7 g/ekor itik Peking umur 8 minggu yang diberi pakan wafer ransum komplit mengandung limbah kulit kopi, dan lebih rendah dibandingkan dengan hasil penelitian Daud et al. (2015) yaitu berkisar antara 1641,7-2150,0 g/ekor itik Peking umur 8 minggu yang diberi hijauan kangkung fermentasi dalam ransum.

\section{Konversi ransum}

Angka konversi pakan menunjukkan tingkat penggunaan pakan dimana jika angka konversi semakin kecil maka penggunaan pakan semakin efisien dan sebaliknya jika angka konversi besar maka penggunaan pakan tidak efisien. Rerata nilai konversi ransum itik Peking penelitian ini berkisar antara 4,19-5,14 (Tabel 2). Nilai konversi ransum pada penelitian ini lebih tinggi dibandingkan dengan hasil penelitian Daud et al. (2015) di mana nilai konversi ransum itik Peking yang diberikan hijauan kangkung fermentasi dalam ransum berkisar antara 3,11-3,93, namun tidak berbeda jauh apabila dibandingkan dengan hasil penelitian Saleh et al. (2006) dengan rerata angka konversi ransum itik Peking yang diberikan tepung bawang putih dalam ransum sebesar 4,30 dan berdasarkan hasil penelitiannya tidak ada pengaruh nyata angka konversi ransum pada itik Peking yang diberikan ransum mengandung tepung bawang putih dengan ransum tanpa penggunaan tepung bawang putih.

Salah satu kelemahan dalam pemeliharaan itik adalah FCR yang cenderung tinggi bila dibandingkan dengan ayam sehingga sangat berpengaruh terhadap nilai input. Buruknya efisiensi penggunaan pakan pada itik petelur maupun pedaging diakibatkan oleh berbagai 
faktor termasuk: (a) Faktor genetik/bibit; (b) Banyaknya pakan tercecer; dan (c) Kandungan gizi pakan yang tidak sesuai kebutuhan (Ketaren 2007). Perilaku makan itik juga mempengaruhi angka FCR seperti yang dilaporkan oleh Ketaren \& Prasetyo (2007) bahwa buruknya konversi pakan itik disebabkan oleh perilaku makan itik termasuk kebiasaan itik yang segera mencari air minum setelah makan. Pakan umumnya terbuang pada saat itik tersebut pindah dari tempat pakan ke tempat minum maupun yang terlarut di dalam wadah air minum. Menurut Siregar et al. (1986) bahwa tingkat konversi ransum sangat tergantung konsumsi ransum yang dihabiskan pada waktu tertentu dibandingkan dengan pertambahan bobot badan yang diperoleh, semakin baik mutu ransum maka angka konversi semakin kecil. Baik tidaknya mutu ransum dapat ditentukan oleh keseimbangan zat-zat makanan yang terkandung dalam ransum.

Suplementasi probiotik dalam ransum juga berpengaruh terhadap tinggi rendahnya angka konversi ransum, sehingga itik yang disuplementasi probiotik dalam ransum dapat memanfaatkan zat-zat makanan dengan baik karena adanya bantuan bakteri pencerna serat dalam saluran pencernaan yang akhirnya meningkatkan bobot badan. Probiotik membantu dalam membentuk keseimbangan mikroflora di dalam saluran pencernaan inang yang selanjutnya berperan untuk menjaga kesehatan inang (Vali 2009). Efek positif yang didapatkan dari terbentuknya keseimbangan mikroflora dalam saluran pencernaan adalah konsumsi pakan dan konversi pakan menjadi efisien (Arslan \& Saatci 2004).

\section{Mortalitas}

Mortalitas atau angka kematian yang menunjukkan jumlah itik yang mati selama pemeliharaan. Kematian yang terjadi umumnya disebabkan oleh faktor penyakit, penyakit tersebut dapat ditularkan melalui faktor mekanis maupun biologis, faktor mekanis peralatan seperti tempat pakan, tempat minum dan lain-lain. Faktor biologis misalnya ternak yang sudah terjangkit penyakit, dan hewan lain yang membawa bibit penyakit. Pengontrolan kesehatan itik diperlukan untuk mencegah terjadinya wabah penyakit dan juga meminimalkan kematian, dengan adanya biosecurity yang baik dapat menghambat terjadinya infeksi sehingga dapat mengurangi jumlah kematian itik (Shandu 2014). Persentase mortalitas itik Peking pada penelitian ini dinyatakan 0\% (tidak terdapat mortalitas) seperti yang ditampilkan pada Tabel 2. Hasil penelitian menunjukkan bahwa pemberian tepung keong mas sampai level $10 \%$ dan suplementasi probiotik dalam formulasi ransum tidak ada pengaruh negatif terhadap mortalitas itik Peking.

\section{KESIMPULAN}

Penggunaan tepung keong mas sampai taraf $10 \%$ dan suplementasi probiotik $0,5 \mathrm{ml}$ dalam formulasi pakan lokal dapat meningkatkan performa itik Peking.

\section{DAFTAR PUSTAKA}

Amarullah M, Nafiu La Ode. 2010. Pemberian keong mas (Pomacea sp.) dalam pakan terhadap penampilan itik bali dan itik tegal. Agriplus. 20:36-41.

Arslan C, Saatci M. 2004. Effect of probiotics admininstation either as feed additive or by drinking water on performance and blood parameters of japanesse quail. Arch Geflugelk. 68:160-163.

Daud M, Fuadi Z, Sultana. 2013. Penggunaan limbah kopi sebagai bahan penyusun ransum itik Peking dalam bentuk wafer ransum komplit. J Agripet. 13:36-42. 
Daud M, Fuadi Z, Mulyadi. 2014. Uji lapang probiotik probiomix plus sebagai suplementasi pakan pada ternak unggas (entoq lokal). J Ilmiah Peternak. 2:59-65.

Daud M, Yaman MA, Zulfan. 2015. Penggunaan hijauan kangkung (Ipomoea aquatica) fermentasi probiotik dalam ransum terhadap performa itik Peking. Dalam: Noor MN, Handiwirawan E, Martindah E, Widiastuti R, Sianturi RSG, Herawati T, Purba M, Anggraeny YN, Batubara A, penyunting. Teknologi Peternakan dan Veteriner untuk Peningkatan Daya Saing dan Mewujudkan Kedaulatan Pangan Hewani. Prosiding Seminar Nasional Teknologi Peternakan dan Veteriner. Jakarta, 8-9 Oktober 2015. Jakarta (Indonesia): IAARD Press. hlm. 479-486.

Daud M, Mulyadi, Fuadi Z. 2016. Persentase karkas itik Peking yang diberi pakan dalam bentuk wafer ransum komplit mengandung limbah kopi. J Agripet. 16:62-68.

Fuller R. 1997. Probiotic 2. Aplication and practical aspects. 1st. Ed. London (UK): Chapman and Hall.

Hernandez F J, Madrid V, Garcia J, Orengo MD, Megias. 2004. Influence of two plants extracts on broilers performance, digestibility, and digestive organ size. Poult Sci. 83:169-174.

Hidayat SCM, Harimurti S, Yusiati LM. 2016. Pengaruh suplementasi probiotik bakteri asam laktat terhadap histomorfologi usus dan performan puyuh jantan. Bul Peternak. 40:101-106.

Jin LZ, Ho YW, Abdullah N, Jalaludin S. 2000. Digestive and bacterial enzyme activities in broilers fed diets supplemented with Lactobacillus cultures. Poult Sci. 79:886-891.

Kartadisastra R. 1997. Pengelolaan pakan ayam. Yogyakarta (Indonesia): Kanisius.

Ketaren PP, Prasetyo LH. 2007. Pengaruh pemberian pakan terbatas terhadap produktivitas itik silang Mojosari × Alabio (MA): Masa pertumbuhan sampai bertelur pertama. JITV. 12:10-15.

Ketaren PP. 2007. Peran itik sebagai penghasil telur dan daging nasional. Wartazoa. 17:117-127.

Mayulu H, Sunarso C, Imam Sutrisno, Sumarsono. 2010. Kebijakan pengembangan peternakan sapi potong di Indonesia. J Litbang Pertan. 29:34-41.

Parakkasi A. 1985. Ilmu gizi dan makanan ternak monogastrik. Bandung (Indonesia): Penerbit Angkasa.

Pramudyati YS. 2002. Pemanfaatan bahan pakan lokal untuk pakan ternak itik. Balai Pengkajian Teknologi Pertanian (BPTP). Sumatera Selatan.

Purba M, Prasetyo IH. 2014. Respon pertumbuhan dan produksi karkas itik pedaging EPMP terhadap perbedaan kandungan serat kasar dan protein dalam pakan. JITV. 19:220-230.

Saleh E, Hertiwahyuni, Saragih. 2006. Pemberian tepung bawang putih (Allium sativum L.) dalam ransum terhadap peforman itik Peking umur 1-8 minggu. J Agribisnis Peternak. (2):3.

Shandu ST. 2014. Duck Health Care. Duck research laboratory, Cornell University of Veterinary Medicine. Ithaca, New York (USA). [Internet]. Available at https://ahdc.vet.cornell.edu/Sects/duck/health.cfm.

Siregar AP, Sabrani, MH, Sutomoprawiro P. 1986. Teknik beternak ayam pedaging di Indonesia. Cetakan ke-2. Jakarta (Indonesia): Margie Group.

Steel RGD, Torrie JH. 1995. Prinsip dan prosedur statistika suatu pendekatan biometrik. terjemahan: Syah M. Jakarta (Indonesia): Gramedia Pustaka Utama.

Vali N. 2009. Probiotic in quail nutrition: a review. Int J Mol Sci. 8:1218-1222.

Wahyu J. 2004. Ilmu nutrisi unggas. Cetakan ke-5. Yogyakarta (Indonesia): Gadjah Mada University Press. 